Ямборська Катерина Сергї̈вна, аспірантка,

Київський національний університет культури імистецтв

\title{
МІСЦЕ МУЗИЧНО-ФОЛЬКЛОРНОЇ ТРАДИЦІЇ У ТВОРЧОСТІ РЕЖИСЕРІВ-ШІСТДЕСЯТНИКІВ: МИСТЕЦЬКІ ПОШУКИ ЛЕОНІДА ОСИКИ
}

У статті, в контексті мистеџьких пошуків режссера Леоніда Осики визначено місие музично-фольклорної традииї як однієї з основних складових у диспуті між представниками напряму радянського сочреалізму та украӥнського поетичного кіно 1960-х років. Проаналізовано значення народної музики як засобу підсилення динамічності та емочійності драматургічної дії в роботах Л. Осики - шедеврах вітчизняної кіномистецької школи - «Камінний хрест» та «Захар Беркут».

Ключові слова: Леонід Михайлович Осика, украӥнське поетичне кіно, «шістдесятники», «Камінний хрест», «Захар Беркут».

В контексте художественных поисков режиссера Леонида Михайловича Осыки в статье определено место музыкально-фольклорной традиции как основной составляющей в диспуте между представителями направления советского сочреализма и украинского поэтического кино 1960-х годов. Проанализировано значение народной музыки как способа усиления динамичности и эмочиональности драматургического действия в работах Л. Осыки - шедеврах отечественной кинематографической школь - «Каменный крест» и «Захар Беркут».

Ключевые слова: Леонид Михайлович Осыка, украинское поэтическое кино, «иестидесятники», «Каменный крест», «Захар Беркут».

In an article in the context of artistic research director Leonid Osyka Mikhailovich the place of music and folk tradition as one of the main components in the dispute between the direction of Soviet socialist realism and Ukrainian poetic cinema of the 1960s. Analyzed the importance of folk music as a means to gain agility and emotion dramatic action in the works of L. Osyka - masterpieces of national kinomystetskoyi school - «Stone Cross» and «Zakhar Berkut».

Key words: Leonid Osyka, Ukrainian poetic cinema, "the Sixties», "Stone Cross», «Zakhar Berkut».

В історії української культури «шістдесятниками» називали покоління національносвідомої інтелігенції, яка увійшла в радянське мистецтво та літературу з другої половини 1950-х років в період тимчасового послаблення комуністично-більшовицького тоталітаризму (лібералізації М. Хрущова) і найповніше творчо виявила себе протягом 1960-х років. Шістдесятники були внутрішньою опозицією до радянського державного режиму, протиставляли себе офіційному догматизму, сповідували свободу мистецького 
самовираження, художній плюралізм, пріоритет загальнолюдських цінностей над класовими тощо. В основі руху шістдесятників у вітчизняному кіномистецтві були Сергій Параджанов, Юрій Іллєнко, Іван Миколайчук, Роман Корогодський, Артур Войтецький, Роллан Сергієнко та ін. Не останнє місце в цьому ряді має ім'я Леоніда Михайловича Осики (1940-2001), який поряд з іншими колегами-однодумцями виступав за справжні культурні цінності, наголошував на оновленні радянського суспільства та утвердженні в ньому національної свободи. Недостатня наукова розробленість проблематики, пов'язаної з кінодіяльністю Л. Осики, особливостями його режисерсько-постановчого стилю зумовлюють актуальність изієї публікації. Метою заявленої дослідницької розвідки стало визначення місця музично-фольклорних традицій у мистецьких пошуках режисера. Досягнення поставленої мети передбачає розв’язання таких завдань:

- проаналізувати історіографію наукової проблеми;

- визначити місце Л. Осики серед вітчизняних режисерів-шістдесятників;

- розглянути кращі роботи кіномайстра періоду поетичного кіно - «Камінний хрест» та «Захар Беркут», з’ясувати в них роль народної музики.

Аналіз наукової літератури доводить, що у вітчизняній історіографії проблеми різнобічні аспекти професійної діяльності Леоніда Осики неодноразово обговорювалися українськими кінознавцями.

Найповніше мистецький шлях режисера було висвітлено ще за життя кіномайстра у виданні «Леонід Осика» (Київ, 1999), створеному кінокритиком Ларисою Брюховецькою [2]. В окремому розділі «Леонід Осика про Леоніда Осику» оприлюднено матеріали, пов'язані з творчістю режисера, подано низку інтерв'ю 3 постановником, у яких йдеться про його роботу над кінострічками, виокремлено думки про сучасну режисуру. У передостанньому розділі зібрано розповіді Леоніда Осики про колег: Сергія Параджанова, Івана Миколайчука, Борислава Брондукова. Завершується книга фільмографією та спогадами сестри режисера Ніни Осики про дитинство, яке випало на роки війни і повоєнний час, а отже, значною мірою сформувало характер творчості кіномитця.

Основні етапи особистого й професійного життя режисера було висвітлено в розгорнутій статті Олександра Безручка «Особливості творчої і педагогічної діяльності Леоніда Михайловича Осики» («Культура і сучасність», 2010, № 2) [1, с. 150-155]. На основі глибокого аналізу джерельної бази, автором публікації було реконструйовано процес становлення Леоніда Осики як педагога і митця; визначено фактори, що вплинули на формування його педагогічних поглядів; прокоментовано особливості його викладацької роботи на кінофакультеті КДІТМ ім. І.Карпенка-Карого.

Важливі роз'яснення щодо властивостей режисерсько-постановчої роботи Леоніда Осики трапляються також у дослідницьких розвідках та інтернет-публікаціях Оксани Бут [3, с. 18-19], Володимира Войтенка [5-6], Сергія Тримбача [13, с. 31]. Науковцями проаналізовано специфічний підхід кіномайстра до трактування народної (сільської) культури та максимального відтворення ії найяскравіших прикмет на екрані; схарактеризовано мелодико-інтонаційну та гармонічно-ритмічну основу кінотворів; віднайдено лінії перетину сюжету і музичного оформлення. 
Важливе місце в історіографії проблеми рівним чином посідають спогади колег Леоніда Осики: композитора Володимира Губи [7, с. 14-17; 8, с. 30-31], актора Івана Гаврилюка [10] та дружини, акторки Світлани Князевої [4], якими було оприлюднено нові, раніше невідомі факти з життя їхнього колеги.

Леонід Осика народився 8 березня 1940 р. в Києві. Закінчив Одеське театральнохудожнє училище, а 1966 р. - режисерський факультет ВДІКу в Москві (майстерня Б. Доліна). Студентом проходив практику на Київській кіностудії ім. О. Довженка у фільмі Володимира Денисенка «Совість» [2, с. 25]. Відомо, що дипломною роботою Л. Осики мала бути стрічка «Та, що входить в море» (1965), в основу якої режисер поклав поетичну алегорію: життя як морський простір.

Підкреслимо, що в музичному оформленні кінокартини було використано одну 3 форм народної художньої звукотворчості - багатоголосні передзвони (відшукуючи тонкі інтонації пластичної дії, Л. Осика позбавив акторів слова, домагаючись, таким чином, гармонії пластики, музики і внутрішньої емоції) [9]. Композитор Володимир Губа, що працював з Леонідом Осикою, згадував про пошук автентичних мотивів до кінополотна: «Мені здавалося, що саме кілька віддалених тихих дзвонів сприяли б одній з ознак нашого християнства та ментальності. Вони налаштовують на різноплановий стан. Це і втрата, і заглибленість у думки. Самі тембри дзвонів позачасові, а також рідні для християнської України. Вони можуть впливати на підсвідомість людини, якщо вона навіть здалеку їх почує, то вже входить у стан містичної концентрації. Вони сприяють добру, красі і спокою...» [8, с. 30-31].

На жаль, дипломна комісія не зарахувала роботу Леоніда Осики, звинувативши іiі у формалізмі. Але несприйняття стрічки не спинило молодого митця. Він своєчасно захистив диплом вже іншим, повнометражним фільмом «Хто повернеться - долюбить» (1968), побудованим у формі епічної панорами втрат, завданих народові війною. Розкриваючи тему високої громадянської місії художника, Леонід Осика створив узагальнюючий образ поета-солдата, використовуючи, насамперед, засоби поетичної кіномови, де філософська глибина поєднувалася з прозорістю оповіді. У рамках подібної стилістики розгорталася дія фільму: вона «то наростала, набираючи стрімку висоту, то, сповнена поетичної символіки та народнопісенної образності, рухалася спокійно, глибоко» [9]. Зорові образи підкріплювалися симфонічною музикою (композитор - В. Губа) з чітко виявленим народнопісенним характером.

Зрежисовані Леонідом Осикою на межі 1960-1970-х років кінокартини «Камінний хрест» (1968) та «Захар Беркут» (1971) визнано сучасними кінознавцями шедеврами української поетичної кіномистецької школи. Ці кінокартини прижиттєво зарахували їх творця до пантеону класиків вітчизняного кінематографу [1, с. 150-155]. Саме в цих фільмах найповніше знайшли відображення такі структурні музично-фольклорні компоненти, як народна пісня, інструментальна музика, танець.

У «Камінному хресті», поставленому за мотивами новел Василя Стефаника («Камінний хрест», «Злодій»; сценарій І. Драча) із великою пластичною силою і психологічною виразністю оповідалася притча «про залишення людьми рідної землі, домівки, які втратили притягуючу силу і спроможність живити і радувати людину» $[13$, c. 31]. Водночас режисер стверджує ідею безсмертя народу: приречений в умовах 
соціального та національного пригнічення, він знаходить силу для поетичного світосприйняття життєвих обставин. Так, головний герой кінотвору (Іван Дідух Д. Ільченко) глибоко усвідомлює, що земля його предків є не лише його годувальницею. Камінний хрест, який він виносить на своїй спині і ставить в полі, це, 3 одного боку, пам'ятник праці, великій любові до рідної землі, з іншого - нагробок зруйнованому селянському патріархальному світу. Хрест постає потужним узагальнюючим символом, що підноситься над буденністю до найвищих висот громадянської свідомості [9].

Варто підкреслити, що протягом всієї картини Леонід Осика залишається вірним Василю Стефанику. Картину тогочасного сільського життя він відтворює настільки достовірно, а соціологічні та психологічні портрети змальовує до такої міри закінчено і конкретно, що матеріал здається документальним (приміром, жителі села Русів Снятинського району Івано-Франківської області, які брали участь у створенні кінофільму, знімалися у власних традиційних строях, пошитих «на смерть») [11, с. 83]. На перший погляд «Камінний хрест» - фільм глибоко поетичний, але поетичність у ньому постає не як засіб або форма, а як фундамент, атмосфера дії. Кінострічка органічно поєднує в собі правду документальності і щирість поезії. Вдумливий вибір акторів (Д. Ільченко, Б. Брондуков, К. Степанков, В. Симчич, А. Лефтій, І. Миколайчук, Б. Савченко тощо), пильний погляд камери в душу героя, уповільнений рух об'єктиву, який створює закінчені гравюри пейзажу - все позначено прагненням режисерапостановника узагальнити, увічнити образ народу-творця [9].

На думку кінознавця С. Тримбача, у «Камінному хресті» простежується пряма полеміка з кінотворчостю пропагандистів соціалістичного реалізму, які оспівували й підносили комуністичні ідеали «до вищого слова» [13, с. 31]. Одним з важливих інструментів цього диспуту виступає в Л. Осики народна пісня, яка досить часто лунає як підсумок дій [3, с. 18-19]. Так, у сцені покарання злодій (Б. Брондуков) не виправдовує себе, а лише співає відому стрілецьку пісню «Десь поїхав в край далекий хлопець милий. Як ішов - лишив дівчині синю чічку». Варто підкреслити, що заявлена, як «народна», пісня з оригінальною назвою «Ой покрились снігом білим полонини, десь поїхав хлопець милий з Буковини. На прощання дав дівчині синю чічку...» належить авторству поета Василя Бобинського та композитора Михайла Гайворонського. Встановлено, що серед січових стрільців музичний твір поширився після його оприлюднення у щоденнику «Українське слово» (Львів, вересень, 1916).

Іншим прикладом використання народної пісні, як засобу підсилення динамічності та емоційності драматургічної дії став фольклорний твір «Із-за гори кам’яної орли вилітають, не знав я розкішоньки - вже літа минають», який лунає у сцені прощання головного героя (Івана Дідуха) з сільською громадою. Пісня привертає до себе увагу експресивністю виконання: «заспівана тріо, по-старовинному, на повний голос плошинним «білим» відкритим тембром, 3 «колінцями» - розспівуючи склади: «Доганяти літа мої, літа мо-о-о-о-лодії....» [3, с. 18-19].

Варто підкреслити, що окрім народних музичних творів, Леонід Осика використав у «Камінному хресті» музику композитора Володимира Губи, яка не зважаючи на ії симфонічність, була наближена за своїм характером до народних музичних творів 
завдяки широкому використанню в ній автентичних музичних інструментів (бандури, цимбал) та церковного хорового співу. В. Губа згодом так описував власні творчі пошуки над звуковим рядом до «Камінного хреста»: «Вже на останньому етапі перезапису в мене з' явилася ще одна важлива пропозиція. По відчуттю не вистачало містичного звуку низької коливаючої струни, яка може викликати асоціації нот бандури, цимбал чи рояля, тобто узагальнений містичний звукотембр. Він виявився напрочуд важливим і необхідним для підсилення сприйняття як першої частини фільму, так і останньої в епізоді, під умовною назвою «Прощання з рідною землею». Коли герої фільму, прості селяни хрестяться і відчувають колихання полум’я рідних свічок [...]. А от у прощальному епізоді кінокартини, де відтворюється документальний церковний спів, інтуїція мені підказувала, що необхідно знайти виконавців похилого віку. Те чуттєве звукове коливання й досі впливає на мою душу і серце...» [8]. Відомо також, що композитору Володимиру Губі разом із звукорежисером Анатолієм Чернооченком вдалося записати випадково віднайдені на горищі однієї з буковинських хат «старі, майже трухляві від часу» і цимбали. «Торкнувши кілька струн, - доповнював власні спогади музикант, - я від здивування завмер. Цей тембр окремих нот мені вдалося самотужки скласти в окремий короткий, щемливий мотив, який супроводжував у фільмі прохід сліпих музикантів...» [8].

Не можна не закцентувати, що в середині 1960-х років радянське суспільство втомилося дослухатися до гасел і промов вождів різного рангу. На часі стало наближення до вічних істин, поза матеріальних цінностей, «постала потреба пізнати життя предків, яке протікало в єдності з природою» та ідеалізувати його [2, с. 63]. Підстави для ідеалізації, на думку Л. Брюховецької надавала саме народна творчість. «Здатність виражати суть речей у барвистих орнаментах, обрядових піснях і дійствах, - пише вона, - здатність сприймати природу як одухотворену - все це притаманне язичницькому світогляду. Збереженість давніх традицій, народного мистецтва в Україні, порівняно 3 іншими країнами, завжди була високою. До речі (і не випадково), одна із визначальних рис естетичної платформи «шістдесятників», а особливо поезії, кінематографа, малярства, - це прагнення виразити природу як субстанцію одухотворену, звернення до мови символів, метафор задля поетичного узагальнення вічних явищ...» [2, с. 63].

У 1971 р., наприкінці періоду українського поетичного кіно, Леонід Осика створює стрічку «Захар Беркут», зняту за мотивами однойменної повісті Івана Франка про подвиг маленької карпатської громади, що вступила в нерівний двобій з татаромонгольськими завойовниками. Слід акцентувати, що режисер досить ретельно слідував за літературним першоджерелом. Така педантичність у відображенні художньої прози на кіноекрані, зумовлювалася на думку сучасних кінокритиків, з одного боку, пошаною до автора геніального твору, з іншого, глибоким розумінням авторського стилю І. Франка, який містив стриманість, об'єктивність у виборі колізій, прагнення до реставрації фресок минулого без штучного домальовування і яскравого гримування [9]. Незважаючи на те, що фільм був відзнятий Л. Осикою на широкоформатній кольоровій плівці, він не мав зайвої екзотики або зовнішньої ефектності; «Захар Беркут» став справжнім історичним кінополотном, де головний тон задає образ Захара Беркута (В. Симчич), створений надзвичайно лаконічними акторськими засобами. «Від цього ще більшої 
вагомості і мудрості набирають кожне слово, жест, а, головне, безперервний рух думки. Захар Беркут гордо несе на своїх плечах прапор гуманності, волелюбства, патріотизму. Це триєдність визначає суть життя і його, і кожного члена суспільства. Це триєдність від далеких предків з покоління в покоління несе український народ» [9].

Композитор Володимир Губа, який працював над оформленням музичної канви «Захара Беркута», дотримувався концепції обробки народних пісень (варіації на тему), що, на думку дослідниці О. Бут, завжди була доброю традицією української композиторської школи. В. Губа широко застосував фольклор як інтонаційно-ритмічну основу кінотвору. Так, для головної лейттеми фільму він обрав мелодію пісні «Цвіте терен», яка «в оркестровому аранжуванні та варіативному розвитку прозвучала як гімн мужності та єдності в подоланні монгольської навали» [3, с. 18-19]. «Взагалі я дуже вдячний Леоніду Осиці за те, - говорив в одному з інтерв'ю В. Губа, - що він завжди мене запрошував із собою в експедиції, бо там я перебував у тому природному середовищі, серед акторів, і матеріал сприймався значно об'єктивніше, ніж коли просто читаєш сценарій...» [7].

Наголосимо, що із закінченням «відлиги» М. Хрущова на початку 1970-х років та зміною державного політичного курсу, в УРСР активізувався процес знищення українського поетичного кінематографу. Фільми, які принесли Леоніду Осиці справжню славу, не змогли захистити його від цькування. Режисерові було потрібно «або пристосовуватися до нових реалій, або шукати іншу роботу, або й навіть розділити гірку долю Сергія Параджанова» [1, с. 150-155]. Актор Іван Гаврилюк згадував: «Осика постійно перебував «під ковпаком» КДБ. Кожний його рух фіксувався. Щоб це припинити, потрібно було лише вступити до Комуністичної партії. Але якби Леонід це зробив, то став би чужим в компанії, до складу якої входили Брондуков, Степанков, Параджанов, Миколайчук, Биков та інші талановиті кіномитці. А Осика займав в цій когорті особливе місце - він був ії совістю [...]. Якій обстругції він був підданий, коли зняв «Камінний хрест»! На ньому як на режисерові хотіли дійсно поставити хрест. Стрічку «зі скрипом» запустили по найнижчій, третій категорії спеціально, щоб їі ніхто не побачив. Формулювання було таким: «Фільм Осики не вписується в межі соцреалізму». А між тим, в Нью-Йоркській кіноакадемії цю картину демонструють як зразок кінорежисури...» [10].

Підсумовуючи викладений у публікації матеріал, акцентуємо на таких висновках. Аналіз джерельної бази досліджуваної теми довів, що визначальні етапи творчої діяльності Леоніда Осики неодноразово обговорювалися у наукових публікаціях вітчизняних кінознавців. Водночас роль і місце музично-фольклорної традиції в оформленні стрічок кіномайстра було розглянуто в них досить побіжно й потребувало ретельнішого вивчення. У контексті українського поетичного кінематографа 1960-х років Леонід Осика став глибоко національним явищем, феноменом, в якому, за влучним формулюванням Л. Брюховецької, одухотворена «родова ознака поетичності проявлялася у реалістичних картинах» [2, с. 14]. Свідомо обираючи сценарії за творами класиків вітчизняної літератури, режисер сповідував принципи фольклорного кіно, які передбачали використання певної стилістики, зокрема, застосування різноманітних форм народної звичаєвості та автентичної художньої творчості. Художні пошуки Леоніда 
Осики виразно віддзеркалювали мистецьке піднесення і занепад українського поетичного кіно 1960-х років. Стрічки «Камінний хрест» і «Захар Беркут» за мистецькою якістю, новаторським експериментом та відсутністю політичної кон'юнктури посідають важливе місце у вітчизняному кіно другої половини ХХ ст. i залишаються свідченням одного з яскравих проявів стихійного вибуху української національної культури у царині кіномистецтва. Використані у кінострічках музичнофольклорні компоненти (народна пісня, інструментальна музика, танець) стали потужним засобом підсилення динамічності та емоційності драматургічної дії, вагомим інструментом диспуту між українським поетичним та тогочасним радянським соцреалістичним кінематографом.

Дослідницька новизна отриманих у ході наукової роботи результатів полягає в тому, що вперше в теорії вітчизняного кіномистецтва проаналізовано значення музичного фольклору в режисерських здобутках Леоніда Осики. Безумовно, визначення місця і ролі народної музики у творчості кіномитця не може обмежуватися лише даною науковою розвідкою і, певна річ, вимагає більш грунтовного кінознавчого аналізу $з$ подальшим викладенням набутих наукових результатів в монографіях з теорії і практики вітчизняного кіномистецтва.

\section{Лimepamypa}

1. Безручко О.В. Особливості творчої і педагогічної діяльності Леоніда Михайловича Осики / О. В. Безручко // Культура і сучасність. - 2010. - № 2. - С. 150-155.2. Брюховецька Л. Леонід Осика / Л. Брюховецька. - Київ: Академія, 1999. - 219 с. 3. Бут О. Пісенний образ в украӥнському кіно / О. Бут // Кіно-театр. - 2010. - № 4. - С. 18-19. 4. Буряк О. Муза й улюблениия геніальних режисерів Світлана Князева / О. Буряк // Подї̈та коментарі. [Електронний ресурс]. - Режим доступу: http://www.gazeta-ptk.org.ua/archives/7267. 5. Войтенко В. «Захар Беркут». Леонід Осика / В. Войтенко // Аргумент-Кіно [Електронний ресурс]. - Режим доступу: http://kinokolo.ua/argument/2399/. 6. Войтенко В. «Камінний хрест». Леонід Осика / В. Войтенко // Аргумент-Кіно [Електронний ресурс]. - Режим достуny: http://kinokolo.ua/argument/2398/. 7. Володимир Губа: «3 Леонідом Осикою у нас була естетична спорідненість» / [розмову вела О. Велимчаниия] // Кіно-театр. - 2012. № 5.-C. 14-17.8. Володимир Губа: «Знайти мистещький код - музичний, кінематографічний» / [розмову вела С. Неумивака]. - Кіно-театр. - 2014. - № 4. - С. 30-31. 9. Знакомьтесь: кинорежиссер Леонид Осыка // МаксАрт. [Електронний ресурс]. - Режим доcmyny: http://maksart.org/kino-2/mastera-kino/osy-ka. 10. Иваничкий С. Иван Гаврилюк: «Увидев мертвого Ивана Миколайчука, Осыка потерял сознание...» / С. Иваницкий // Факти. - 2010. - 19 марта. 11. Юрченко В. Несподіваний фільм Леоніда Осики / В. Юрченко // Кіно-театр. - 2002. - № 3. - С. 16-18. 12. Тримбач С. Екранні медіа і нові технологї в контексті сучасної доби / С. Тримбач // Стратегї̈ дослідження екранних медіа / НАН України; ІМФЕ ім. М. Т. Рильського. -Київ, 2013. - 356 с. 